\title{
PERBANDINGAN WATERFALL MODEL DAN METODE GENERIK DALAM MANAJEMEN PROYEK PERANGKAT LUNAK SISTEM PENGELOLAAN DANA BANTUAN OPERASIONAL SEKOLAH (BOS) (STUDI KASUS: MAN 1 KOTA LHOKSEUMAWE)
}

\author{
Hari Toha Hidayat \\ Program Studi Teknik Multimedia dan Jaringan Komputer \\ Jurusan Teknologi Informasi \& Komputer Politeknik Negeri Lhokseumawe \\ e-mail: haritoha@pnl.ac.id
}

\begin{abstract}
Making the software is not an easy job. If we are going to make an application then the required expertise in programming. However, mastery in the field of programming is not enough should have knowledge of project management software. Project management is an important part of software development. The research methodology used the case study of the application making the management of school operational funds in MAN 1 Lhokseumawe. Comparison of two methods of design that is between a generic method with the Waterfall model of result whereby the generic has stages that detailed when compared with the Waterfall model of simple and modest. Based on the research conducted in the making of software projects with short time such as within 1 month then it is better to use the method Waterfall design. But if the work over a long period of about one year and applications are built complex and large then you should use a generic method
\end{abstract}

Keywords: Project management, Waterfall, Generic methods

\section{INTISARI}

Pembuatan perangkat lunak bukanlah suatu pekerjaan yang mudah. Apabila kita akan membuat suatu aplikasi maka dibutuhkan keahlian dibidang pemrograman. Akan tetapi, penguasaan dalam bidang pemrograman tidak cukup harus memiliki pengetahuan tentang manajemen proyek perangkat lunak. Manajemen proyek merupakan bagian yang penting dalam pembangunan perangkat lunak. Adapun metodologi penelitian yang digunakan yakni studi kasus terhadap pembuatan aplikasi pengelolaan dana bantuan operasional sekolah di MAN 1 Lhokseumawe. Perbandingan dua metode perancangan yakni antara metode generik dengan Waterfall model diperoleh hasil dimana pada metode generik memiliki tahapan yang detail jika dibandingkan dengan Waterfall model yang simpel dan sederhana. Berdasarkan dari penelitian yang dilakukan maka dalam pembuatan proyek perangkat lunak dengan tempo yang singkat seperti dalam waktu 1 bulan maka lebih baik menggunakan metode perancangan Waterfall. Akan tetapi jika pengerjaan dalam waktu yang panjang sekitar 1 tahun dan aplikasi yang dibangun kompleks dan besar maka sebaiknya menggunakan metode generik

Kata kunci: Manajemen proyek, Waterfall, Metode generik

\section{PENDAHULUAN}

Pembuatan perangkat lunak bukanlah suatu pekerjaan yang mudah. Apabila kita akan membuat suatu aplikasi maka dibutuhkan keahlian dibidang pemrograman. Akan tetapi, penguasaan dalam bidang pemrograman tidak cukup harus memiliki pengetahuan tentang manajemen proyek perangkat lunak. Hal ini penting dilakukan supaya aplikasi yang dihasilkan sesuai dengan kebutuhan pengguna dan proyek yang ditangani tidak rugi. Banyak pihak dalam melakukan proyek dalam bidang perangkat lunak yang mengalami kegagalan. Kegagalan tersebut bisa terjadi dari aplikasi yang tidak bisa memenuhi kebutuhan pengguna bisa juga dari sisi manajemen proyek yang tidak sesuai dengan perencanaan. Apabila proyek tersebut gagal maka banyak pihak yang akan dirugikan.

[3] Manajemen proyek merupakan bagian yang penting dalam pembangunan perangkat lunak. Tentunya manajemen ini dibutuhkan oleh para manajer atau pemimpin proyek sehingga 
hasil yang didapat sesuai dengan kebutuhan. Salah satu kasus yang akan dibahas pada jurnal ini adalah pembangunan proyek perangkat lunak pengelolaan dana bantuan operasional sekolah (BOS) pada MAN 1 Kota Lhokseumawe. Dalam pembuatan perangkat lunak ini akan menghasilkan monitoring penggunaan dana bos sampai dengan proses pembuatan laporan penggunaan dana bos.

[1] Proyek adalah urutan kegiatan yang unik, kompleks, dan saling terkait, memiliki satu tujuan, dan tujuan harus diselesaikan dalam waktu tertentu, sesuai anggaran dan memenuhi spesifikasi. Macam - macam proyek IT yang dapat diperoleh adalah sebagai berikut:

a. Pengadaan perangkat keras (hardware)

b. Pengembangan perangkat lunak (software)

c. Pemeliharaan perangkat lunak (software)

d. Konsultasi IT (biasanya dilakukan oleh konsultan IT)

Manajemen proyek perangkat lunak sangat dibutuhkan karena permasalahan yang sering timbul pada proyek perangkat lunak tanpa pengelolaan yang baik adalah pembengkakan biaya proyek dan waktu pengerjaan tidak sesuai rencana (molor waktu). Padahal waktu dan biaya biasanya sudah dianggarkan oleh pelanggan (customer) dan developer perangkat lunak harus mampu mengelolanya agar target perangkat lunak yang akan dibuat dapat dicapai.

Aktifitas manajemen perangkat lunak adalah sebagai berikut:

\section{A. Manajemen Aktivitas Proyek}

Aktifitas yang dilakukan pada proyek perangkat lunak adalah sebagai berikut:

1. Menulis proposal

2. Perencanaan dan penjadwalan

3. Pembiayaan proyek

4. Pengawasan dan peninjauan proyek

5. Seleksi dan evaluasi anggota proyek

6. Penulisan laporan dan presentasi

B. Perencanaan Proyek

Perencanaan proyek biasanya terdiri dari:

1. Organisasi proyek

2. Analisis resiko

3. Kebutuhan perangkat keras dan perangkat lunak

4. Pembagian kerja

5. Penjadwalan proyek
6. Mekanisme pengawasan dan pelaporan

C. Penjadwalan Proyek

Hal-hal yang perlu dilakukan pada penjadwalan proyek adalah sebagai berikut:

1. Membagi kerja proyek menjadi lebih kecil dan memperkirakan waktu, sumber daya, dan personel untuk melakukan tiap bagian kerja

2. Mengatur urutan pembagian kerja

3. Meminimalisasi kebergantungan setiap bagian kerja agar tidak terjadi banyak waktu kosong (delay) karena saling menunggu bagian kerja lain selesai lebih dulu

4. Penjadwalan yang baik bergantung pada intuisi dan pengalaman pengelola proyek

D. Manajemen Resiko

Manajemen resiko fokus pada mengidentifikasi resiko dan membuat perencanaan yang dapat meminimalisir resiko yang mungkin terjadi pada proyek perangkat lunak. Resiko yang biasanya terjadi pada proyek perangkat lunak adalah sebagai berikut:

1. Resiko proyek

Resiko pada penjadwalan dan sumber daya (biasanya kurang karena ketidaksesuaian dengan perencanaan). Resiko proyek yang mungkin terjadi adalah sebagai berikut:

a. Pergantian orang di dalam proyek

b. Perubahan pengelolaan

c. Tidak tersedianya perangkat keras

2. Resiko produk

Resiko yang terjadi pada proyek dapat membuat perangkat lunak yang dihasilkan tidak sesuai harapan. Resiko produk yang mungkin terjadi adalah sebagai berikut:

a. Perubahan spesifikasi / kebutuhan produk

b. Keterlambatan waktu pengumpulan kebutuhan (biasanya terjadi karena pelanggan (customer) tidak siap dengan apa yang sebenarnya mereka butuhkan)

c. Besarnya sistem tidak dapat diperkirakan

d. Perangkat pendukung proyek tidak ada 
3. Resiko bisnis

Resiko bisnis dapat menyebabkan masalah pada organisasi proyek dan proses produksi perangkat lunak. Resiko bisnis yang sering terjadi adalah sebagai berikut:
a. Perubahan teknologi
b. Persaingan produk

Memimpin sebuah proyek perangkat lunak bukanlah merupakan hal yang mudah. Diperlukan ketajaman analisis untuk menganalisis semua kebutuhan proyek yang dapat menimbulkan resiko proyek. Terjadinya resiko dalam proyek perangkat lunak dapat menyebabkan biaya membengkak atau waktu pengerjaan yang molor berkepanjangan. Maka dari itu diperlukan pengalaman yang baik untuk menanggulangi semua resiko yang mungkin muncul.

\section{METODOLOGI PENELITIAN}

Adapun metodologi penelitian yang diguanakan yakni studi kasus terhadap pembuatan aplikasi pengelolaan dana bantuan operasional sekolah di MAN 1 Lhokseumawe. Pendekatan dalam penelitian ini adalah pendekatan secara empiris berdasarkan pengalaman dan teori yang berkaitan dengan manajemen proyek.

Perancangan sistem yang digunakan dalam membangun aplikasi pengelolaan dana BOS seperti pada Gambar 1.

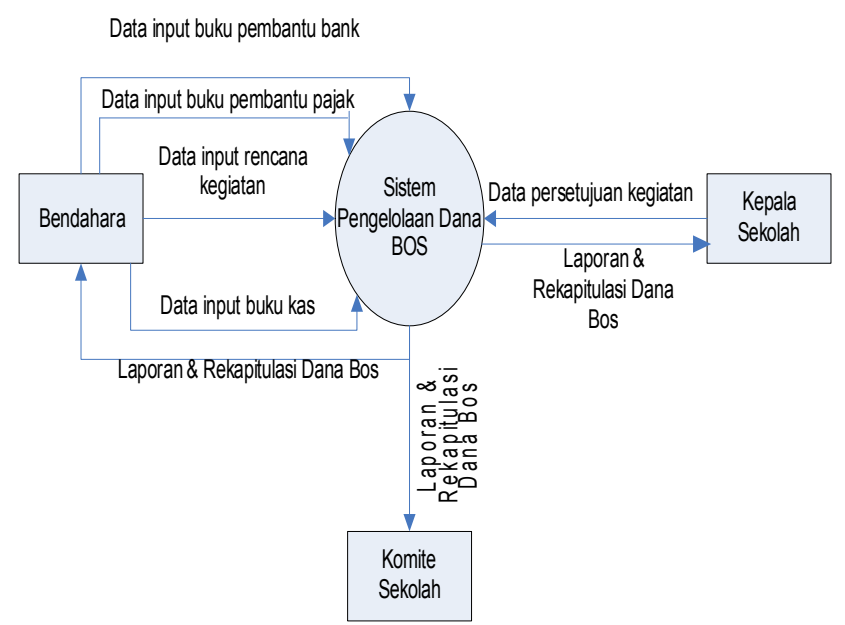

Gambar 1. Diagram konteks perancangan sistem

\section{PERANCANGAN}

\section{A. Model Generik}

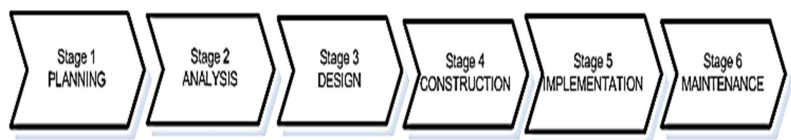

Gambar 2. Model Generik (Sumber: Richardus Eko, 2012)

\section{Planning}

Tahap ini merupakan langkah pertama berupa perencanaan. Langkah ini merupakan suatu kegiatan semenjak ide pertama yang melatarbelakangi pelaksanaan proyek ini didapat, pendefinisian awal terhadap kebutuhan detil atau target yang harus dicapai dari proyek tersebut, penyusunan proposal, penentuan metodologi dan sistem manajemen proyek yang digunakan, sampai dengan penunjukkan tim dan instruksi untuk mengeksekusi (memulai) proyek yang bersangkutan. Biasanya ada dua pihak yang terlibat langsung dalam proyek perencanaan ini. Pihak pertama adalah pihak yang membutuhkan eksistensi dari suatu sistem informasi, dalam hal ini adalah perusahaan, lembaga, institusi, atau organisasi yang bersangkutan. Pihak kedua adalah pihak yang berusaha menjawab kebutuhan tersebut dalam bentuk pengembangan teknologi informasi.

\section{Analysis}

Secara prinsip ada dua aspek yang menjadi fokus analisa yaitu aspek bisnis dan aspek teknologi. Adapun tujuan dilakukannya analisis pada aspek bisnis adalah:

a. Mengetahui posisi atau peranan teknologi informasi yang paling sesuai dan relevan di perusahaan.

b. Mempelajari fungsi - fungsi manajemen dan aspek - aspek bisnis terkait yang akan berpengaruh terhadap proses desain, konstruksi dan implementasi.

Tujuan analisis pada aspek teknologi adalah:

1. Mempelajari infrastruktur teknologi informasi yang dimiliki perusahaan dan efektivitas penggunaannya selama kurun waktu tersebut.

2. Menganalisis kemungkinan - kemungkinan diperlukannya penambahan sistem di kemudian hari sehubungan akan diimplementasikannya teknologi baru. 


\section{Design}

Pada tahap ini tim teknologi informasi bekerja sama dengan tim bisnis atau manajemen melakukan perancangan komponen - komponen sistem terkait. Tim teknologi informasi akan melakukan perancangan teknis dari teknologi informasi yang akan dibangun seperti sistem basis data, jaringan komputer, metode interfacing, teknik konversi data, dan metode migrasi sistem. Sementara secara paralel dan bersama - sama tim bisnis atau manajemen akan melakukan perancangan terhadap komponen organisasi yang terkait seperti standar operasional prosedur (SOP), struktur organisasi, kebijakan - kebijakan, teknik pelatihan, dan pendekatan SDM. Output dari tahapan ini berupa blue print rancangan sistem yang akan dijadikan pegangan pada tahap konstruksi dan implementasi.

\section{Construction}

Berdasarkan desain yang telah dibuat, konstruksi atau development sistem yang sesungguhnya dibangun. Dari semua tahapan, tahap konstruksi inilah yang melibatkan sumber daya besar, terutama dalam hal SDM, biaya dan waktu. Kontrol terhadap tahapan ini haruslah diperketat agar tidak terjadi ketidakefisienan maupun ketidakefektivan dalam penggunaan sumber daya yang ada, yang bisa berdampak terhadap keberhasilan proyek. Hasil akhir dari tahapan ini berupa uji coba sistem dan perbaikan - perbaikan bersifat minor.

\section{Implementation}

Tahap implementasi merupakan tahapan yang kritis karena untuk pertama kalinya sistem informasi akan digunakan. Biasanya ada dua pendekatan yang digunakan yakni cut-off atau paralel. Cut-off atau dikenal dengan big-bang dimulai terhitung pada hari tersebut sistem baru mulai dipergunakan dan sistem lama sama sekali ditinggalkan. Sedang pendekatan paralel dilakukan dengan pengenalan sistem baru sementara sistem lama belum ditinggalkan, sehingga yang terjadi adalah berjalannya dua buah sistem secara paralel. Pada tahapan ini pemberian pelatihan atau training harus diberikan kepada semua pihak yang terlibat sebelum tahap implementasi dimulai. Selain untuk mengurangi resiko kegagalan, pemberian pelatihan juga berguna untuk menanamkan rasa memiliki terhadap sistem baru yang diterapkan, sehingga seluruh jajaran pengguna atau SDM akan denga mudah menerima sistem baru tersebut dan memeliharanya di masa-masa mendatang dengan baik.

\section{Maintenance}

Tahap pasca implementasi berupa suatu aktivitas, dimana harus ada personel atau divisi dalam perusahaan yang dapat melakukan perubahan atau modifikasi terhadap sistem informasi sejalan dengan perubahan kebutuhan bisnis yang teramat sangat dinamis.

\section{B. Model Waterfall}

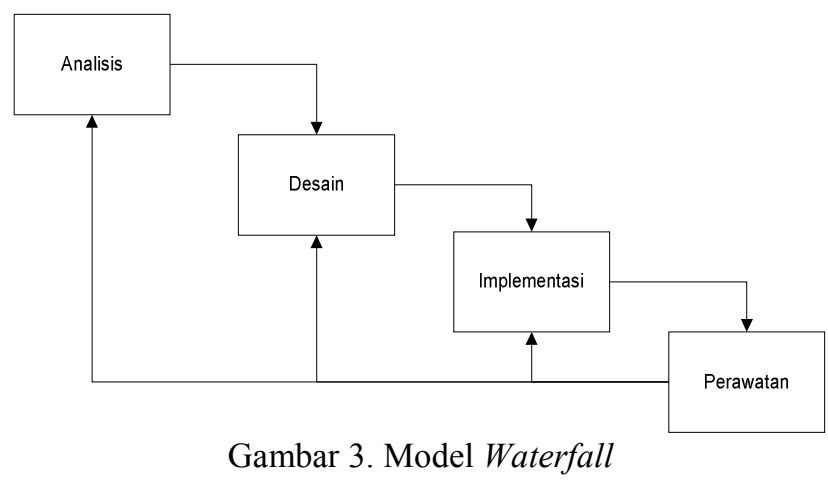

\section{Analisis}

Pada tahap ini yakni melakukan proses pengumpulan kebutuhan dilakukan secara intennsif untuk memspesifikasikan kebutuhan perangkat lunak agar dapat dipahami perangkat unak seperti apa yang dibutuhkan oleh user.

\section{Desain}

Desain perangkat lunak adalah proses multi langkah yang fokus pada desain pembuatan program perangkat lunak termasuk struktur data, arsitektur perangkat lunak, representasi antarmuka, dan prosedur pengodean. Tahap ini mentranslasi kebutuhan perangkat lunak dari tahap analisis kebutuhan ke representasi desain agar dapat diimplementasikan menjadi program pada tahap selanjutnya.

\section{Implementasi}

Desain harus ditranslasikan ke dalam program perangkat lunak. Hasil dari tahap ini adalah program komputer sesuai dengan desain yang telah dibuat pada tahap desain. Di tahap ini juga aplikasi yang telah dibuat diperkenalkan pada pengguna untuk dipakai. Dalam implementasi juga dibutuhkan pemberian pelatihan pada pengguna. Hal ini 
dilakukan agar pengguna menjadi terbiasa dengan sistem baru yang digunakan.

4. Perawatan

Pada tahap ini perawatan pasca implementasi perlu dilakukan sebagai wujud tanggung jawab pihak pengembang kepada pengguna. Dalam proses perawatan ini pihak pengembang memberikan pelatihan pada personel yang akan ditunjuk sebagai pihak IT untuk bisa melakukan perubahan dan modifikasi terhadap sistem.

\section{HASIL DAN PEMBAHASAN}

Perbandingan dua metode perancangan yakni antara metode generik dengan Waterfall model diperoleh hasil dimana pada metode generik memiliki tahapan yang detail jika dibandingkan dengan Waterfall model yang simpel dan sederhana.

Pada metode generik tahap - tahap yang dilalui sangatlah detail tentunya ini bagus dalam pembangunan suatu perangkat lunak. Pada metode ini memiliki kelebihan dibandingkan dengan metode Waterfall. Dimana pada metode generik memiliki tahapan perencanaan yang matang dan detail, selain itu pada metode ini memiliki tahap konstruksi sebelum tahap implementasi. Tentunya ini akan membuat aplikasi yang dibangun lebih baik. Pada tahap konstruksi ini seorang analis sistem melakukan uji coba desain sistem yang dirancangnya. Apakah desain dan logika tersebut sudah benar atau belum. Tentunya ini akan sangat membantu programmer pada tahap implementasi dalam membuat programnya dengan baik tanpa ada kesalahan lagi.

Akan tetapi, metode generik ini tidak tepat jika digunakan dalam proyek dengan jangka waktu yang pendek seperti 30 hari kalender. Metode ini cocoknya jika digunakan untuk pengerjaan proyek dengan jangka waktu 1-2 tahun.

Sementara itu, untuk metode Waterfall model memiliki tahapan yang lebih sederhana dibandingkan dengan metode generik. Kelebihan dari metode Waterfall ini bisa digunakan untuk pengerjaan proyek dengan tempo yang pendek seperti dalam waktu 1-3 bulan. Kekurangan yang dimiliki dari metode Waterfall adalah tidak tepat jika digunakan untuk membangun perangkat lunak yang kompleks dan berkapasitas besar seperti pembuatan aplikasi SIM RS.

Pada penelitian ini peneliti lebih menggunakan metode Waterfall. Hal ini disebabkan pembuatan aplikasi pengelolaan dana BOS di MAN 1 lhokseumawe hanya dalam waktu 1 bulan. Anggota tim yang dilibatkan pun hanya berjumlah dua orang saja yakni analis sistem dan programmer. Penggunaan sumber daya yang tidak banyak disebabkan proyek ini hanyalah proyek kecil.

Adapun hasil yang diperoleh dari pembuatan aplikasi pengelolaan dana BOS di MAN 1 Lhokseumawe sebagai berikut:

1. Master data dari aplikasi

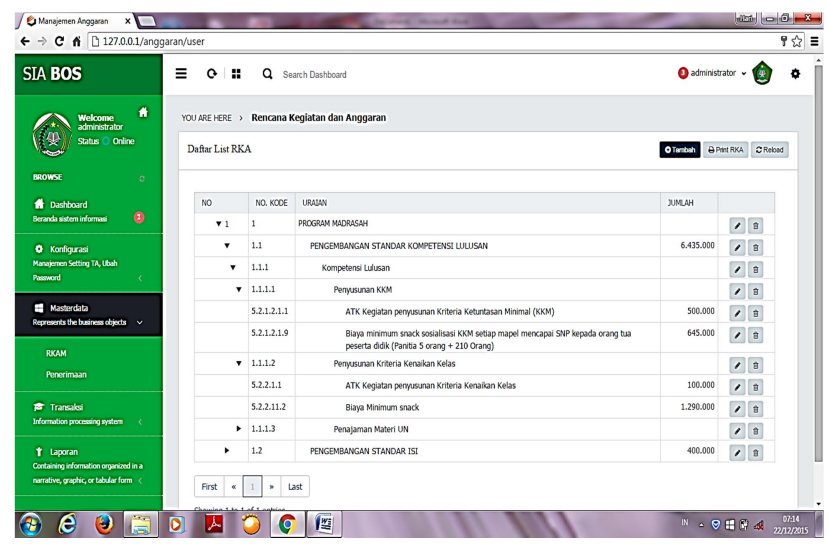

Gambar 4. Master data

2. Transaksi bank

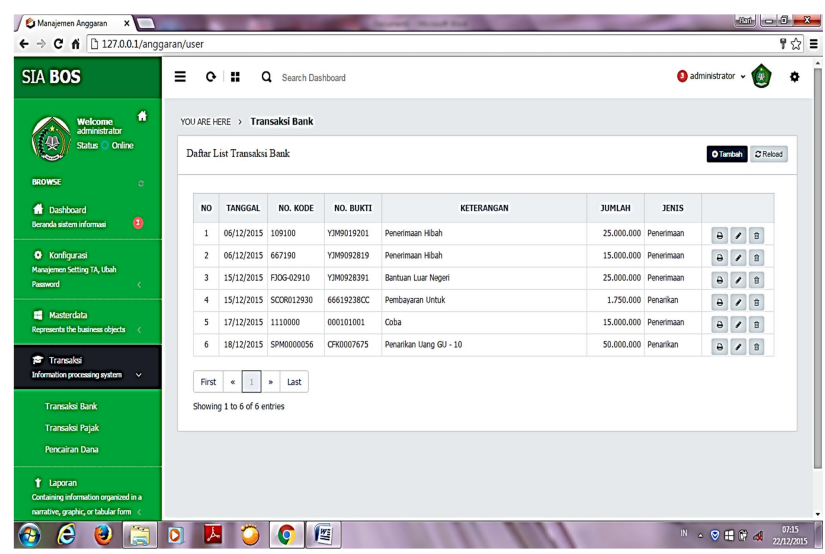

Gambar 5. Transaksi Bank 
3. Pencairan Dana

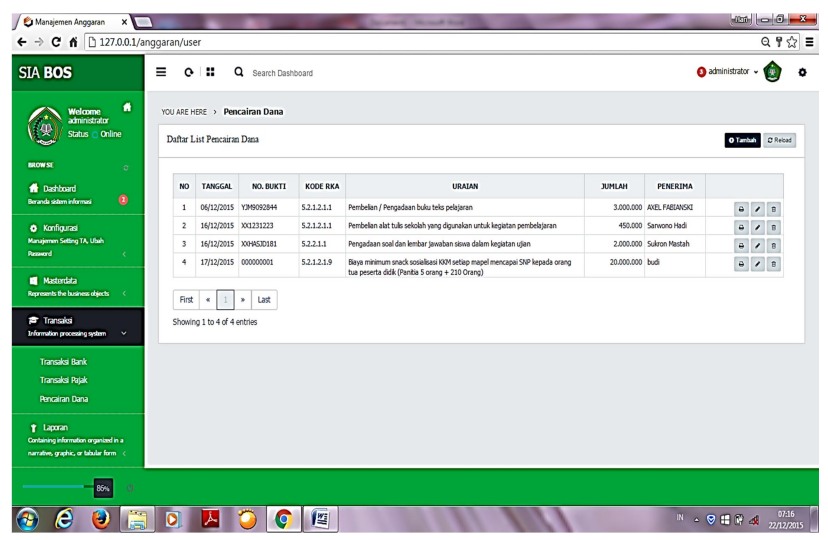

Gambar 6. Pencairan dana

4. Laporan Buku Pembantu Kas

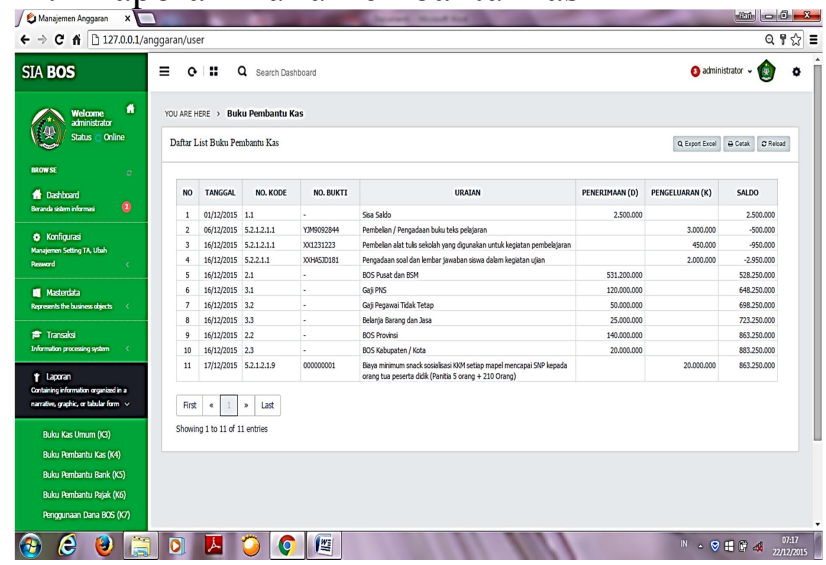

Gambar 7. Laporan buku pembantu kas

5. Laporan Penggunaan Dana Bos

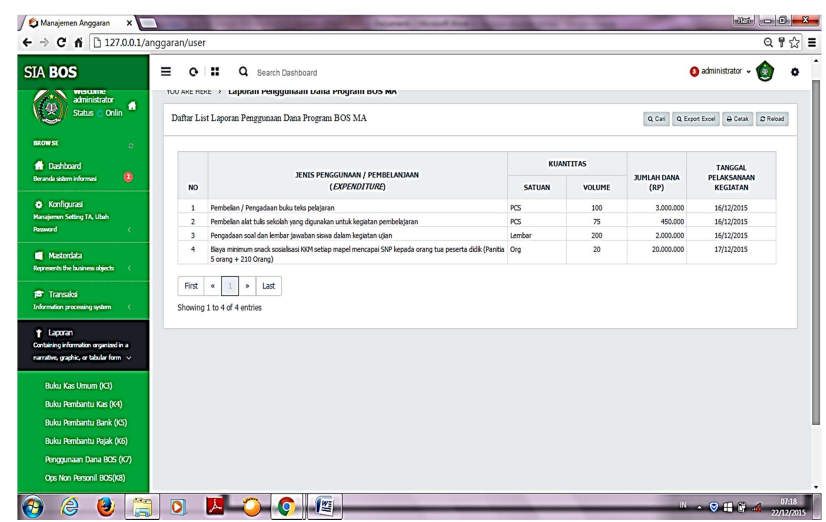

Gambar 8 Laporan penggunaan dana bos

\section{KESIMPULAN}

Berdasarkan dari penelitian yang dilakukan maka dalam pembuatan proyek perangkat lunak dengan tempo yang singkat seperti dalam waktu 1 bulan maka lebih baik menggunakan metode perancangan Waterfall. Akan tetapi jika pengerjaan dalam waktu yang panjang sekitar 1 tahun dan aplikasi yang dibangun kompleks dan besar maka sebaiknya menggunakan metode generik.

\section{REFERENSI}

[1]. Rosa, A. S. dan Shalahuddin, M. (2013). "Rekayasa Perangkat Lunak", Penerbit Informatika, Bandung.

[2]. Arief (2010). "Pengantar Rekayasa Perangkat Lunak", Modul Universitas Gunadarma,

http://elearning.gunadarma.ac.id/docmodu 1/index-

pengantar rekayasa perangkat lunak.htm

[3]. Primawati, A. (2011). "Analisis Manajemen Proyek Perangkat Lunak Sistem Informasi Akuntansi Pada Biro Sistem Informasi PT.X”'. Tesis Universitas Indraprasa PGRI. Jakarta

[4]. Proboyekti, U. (2009). "Konsep Desain Software", Modul Ajar UKDW, http://lecturer.ukdw.ac.id/othie/softdesign. pdf (tanggal akses 24 Oktober 2015) 